\title{
Urgensi Mahkamah Konstitusi dalam Proses Pemberhentian Presiden
}

\author{
R. Nazriyah
}

\begin{abstract}
The existence of Constitution Court as the pioneer of constitution in Indonesia must be warmly responded, because through this board it will be found the solution from the jurisdictive aspect when the institutional conflict of arise.between House of Representatives and President which start from the House of Representatives' ideas that President or the vice President has broken the law.
\end{abstract}

\section{Pendahuluan}

Berdasarkan kewenangan yang diberikan oleh Pasal 37 UUD 1945 sejak 1999 sampai tahun 2002 MPR telah melakukan empat kali perubahan UUD 1945. Perubahan pertama dilakukan dalam Sidang Umum MPR 1999, perubahan kedua dalam Sidang Tahunan MPR 2000, perubahan ketiga dalam Sidang Tahunan MPR 2001 dan perubahan keempat dilakukan dalam Sidang Tahunan MPR 2002 yang telah lalu.

Tuntutan terhadap perubahan konstitusi atau UUD dikarenakan tidak ada satu sistem ketatanegaraan yang digambarkan dalam konstitusi atau UUD secara sempurna pada saat dilahirkan, karena proses kelahiran suatu konstitusi di setiap negara berbeda-beda alasan dan latar belakang historisnya, dia adalah produk zamannya.

UUD 1945 adalah produk masanya, sebagai hasil pemikiran para negarawan yang menyusunnya pada waktu itu. Dalam kurun waktu perkembangannya mungkin saja terasa ada sesuatu yang perlu diubah untuk disempurnakan. sebagai perangkat sistem ketatanegaraaan Indonesia. Maka sesuai dengan perkembangan zaman dan dinamika ketatanegaraan salah satu materi muatan yang menjadi kebutuhan kita adalah terbentuknya Mahkamah Konstitusi.

Dengan berubahnya struktur parlemen menjadi "dua kamar" (bikamera)" yang terdiri

'Rumusan UUD 1945 baru, sama sekali tidak mencerminkan konsep sistem perwakilani duakamar. MPR mempunyai anggota dan lingkungan wewenang sendiri. Demikian pula DPR dan DPD. Hal semacam ini bukan system dua kamar, tetapi malahan menjadi tiga badan perwakilan yang mandiri (DPR, DPD, dan MPR). Sebagaimana dikemukakan oleh Bagir Manan, DPR, DPD dan MPR dalam UUD 1945 Baru. Cet. 1, (Yogyakarta: FH-Ull Press, 2003), hlm. 5. 
atas Dewan Perwakilan Rakyat dan Dewan Perwakilan Daerah, kedua kamar parlemen tersebut secara bersama-sama tetap dapat disebut sebagai Majelis Permusyawaratan Rakyat, seperti Kongres Amerika Serikat yang terdiri atas House of Representatives dan Senat. ${ }^{2}$

Sehubungan dengan gagasan cheks and balance, penyelesaian sengketa di antara lembaga negara yang sederajat itu perlu diatur mekanismenya. Jika dulu, Majolis Permusyawaratan Rakyat yang berkedudukan sebagai lembaga tertinggi negara penjelmaan seluruh rakyat dan pelaku sepenuhnya kedaulatan rakyat Indonesiaberwenang dan memang merupakan pemegang kekuasaan tertinggi untuk mengatasi persengketaan semacam itu, maka sekarang sudah dibentuk suatu Mahkamah tersendiri yang dinamakan Mahkamah Konstitusi. ${ }^{3}$

Mahkamah Konstitusi merupakan lembaga negara baru yang diintrodusir melalui perubahan UUD 1945. Dari sudut pandang Hukum Tata Negara perlunya dibentuk Mahkamah Konstitusi adalah untuk memeriksa, mengadili dan memutuskan pendapat DPR terhadap perbuatan Presiden dan/ atau Wakil Presiden yang diduga melanggar hukum, sebagaimana yang tercantum dalam Pasal 24C ayat (2): "Mahkamah Konstitusi wajitb memberikan putusan atas pendapat Dewan
Perwakilan Rakyat mengenai dugaan pelanggaran oleh Presiden dan/atau Wakil Presiden menurut Undang-Undang Dasar".

Dengan terjadinya perubahan mekanisme pemberhentian Presiden dan/atau Wakil Presiden melalui perubahan UUD 1945 tersebut, maka dalam tulisan ini yang ingin dikaji adalah urgensi Mahkamah Konstitusi dalam proses pemberhentian Presiden dan/ atau Wakil Presiden.

\section{Sejarah Mahkamah Konstitusi}

Salah satu ketentuan baru yang sangat penting yang terdapat dalam Perubahan Ketiga Undang-Undang Dasar 1945 adalah ketentuan mengenai Mahkamah Konstitusi yang dirumuskan dalam Pasal $24 C$ ayat (1) sampai dengan ayat $(6) .{ }^{4}$ Perkembangan ide Mahkamah Konstitusi ini dapat dikatakan relatif baru di Indonesia. Bahkan di seluruh dunia, negara yang telah memiliki lembaga baru ini tercatat 78 buah negara. Dalam perkembangan pemikiran hukum dan kenegaraan modern, gagasan Mahkamah Konstitusi (constitutional court) ini di dunia, dapat disebut merupakan hasil temuan dan kreasi abad ke-20. Lembaga ini dianggap penting dalam rangka memperkuat usaha membangun hubungan-hubungan yang saling mengendalikan antar cabang-cabang kekuasaan negara (cheks and balances).

${ }^{2}$ Menurut penulis, kedua lembaga tersebut (MPR dan Kongres) mempunyai kemiripan tetapi tidak sama, MPR mempunyai tugas dan wowenang sendiri sedangkan Kongres tidak mempunyai tugas dan wewenang sama sekali. Kongres hanya merupakan Forum bertemunya Senat dan House of Representatives.

3.Jimly Asshiddiqie, "Mahkamah Konstitusi di berbagai Negara," Seminar Regional Kedudukan, Fungsi dan Kompetensi Mahkamah Konstitusi dalam Sistem Ketatanegaraan Republik Indonesia, diselenggarakan oleh Program Doktor(S3) IImu Hukum, Universitas Islam Indonesia, Yogyakarta, 11 Mei 2002, hlm. 1.

4Jimly Asshiddiqie, Konsolidasi Naskah UUD 1945 Setelah Perubahan Keempat (Jakarta: Pusat Studi Hukum Tata Negara FH-UI, 2002), hlm. 40-44. 
Pada mulanya, ${ }^{5}$ kegunaan praktis Mahkamah Konstitusi ini berkaitan dengan keperluan untuk mengadakan pengujian terhadap konstitusionalitas undang-undang yang ditetapkan oleh parlemen. Perdebatan mengenai persoalan ini pada mulanya muncul dan berkembang di Amerika Serikat dalam kasus yang terkenal, yaitu 'Madison versus Marbury' tahun 1803. Inti perdebatan dalam kasus ini adalah bahwa Mahkamah Agung Amerika Serikat di bawah pimpinan John Marshall ditantang untuk melakukan pengujian (review atau toetsing) atas konstitusionalitas undang-undang yang ditetapkan oleh Kongres, sementara Konstitusi Amerika Serikat sama sekali tidak memberikan kewenangan kepada Mahkamah Agung untuk molakukan upaya yang pada pokoknya bersifat mempersoalkan produk hukum yang dibuat oleh kongres yang merupakan cabang kekuasaan legislatif.

Namun, berkat keberaniannya berinovasi (berijtihad), John Marshall selaku Ketua Mahkamah Agung ketika itu, menetapkan bahwa Mahkamah Agung memiliki kewenangan menguji undang-undang sebagai produk lembaga legislatif meskipun hal itu tidak bersifat 'constitutiona'lly entrusted power'. Hak menguji inilah yang biasa disebut dengan 'judicial review' atau dalam bahasa Belandanya disebut "foetsingsrecht" yang dianggap sudah dengan sendirinya dimiliki oleh Mahkamah Agung Amerika Serikat sebagai "the Guardian of the Constitution of the United States of America".

Kasus 'Madison versus Marbury' ini sangat fenomenal, karena membuat preseden baru dalam sejarah hukum Amerika. Sejak itu, pengaruhnya meluas ke dalam pemikiran dan praktek-praktek hukum di banyak negara. Pengaruhnya bahkan juga meluas ke Eropa, Asia dan Afrika. Memberikan peran kepada lembaga kehakiman untuk menguji produk lembaga' legislatif diterima umum sebagai mekanisme yang dinilai penting untuk menjamin tegaknya negara hukum modern (modern democratische rechtsstaat) dan memperkuat sistem demokrasi negara modern (modern constitutional democracy). ${ }^{6}$

Pada perkembangan selanjutnya, di samping karena makin meningkatnya kesadaran mengenai pentingnya fungsi 'judicial review' itu, diberbagai negara muncul pula kebutuhan untuk menghadapi berbagai kasuskasus perselisihan antar cabang-cabang kekuasaan negara yang tidak dapat diselesaikan dengan cara-cara yang lazim oleh lembaga-lembaga yang ada, termasuk oleh Mahkamah Agung. Karena itu, di lingkungan negara-negara Eropa Barat, seperti Austria, Jerman, Italia, Perancis, dan Belgia, yang pada umumnya menganut tradisi 'civil law', fungsi pengujian dan penyelesaian sengketa oleh hakim tersebut (judicial review) dianggap perlu dilembagakan secara tersendiri dalam struktur ketatanegaraan mereka. Karena itu, berkembanglah ide untuk membentuk Mahkamah Konstitusi (Constitutional Court) yang tersendiri di luar struktur Mahkamah Agung (Supreme Court of Justice) yang sudah ada sebelumnya.

Negara yang dianggap pelopor dalam membentuk Mahkamah ini di Eropa adalah Austria yang mengadopsikan ide pembentukan

\footnotetext{
SJimly Asshiddiqie, Mustafa Fakhri, Mahkamah Konstitusi Kompilasi ketentuan Konstitusi, Undang-Undang dan Peraturan di 78 Negara, Pusat Stuơ HTN FHUl. Asosiasi Pengajar HTN dan HAN Indonesia, hlm. 1

${ }^{B}$ Ibid.
} 
Mahkamah Konstitusi itu dalam UỤD 1920. Mahkamah Konstitusi Austria yang sekärang ini a ada telah berdiri dan menjalankan tugas konstitusionalnya sejak kemerdekaan Austria dari Jerman pada 1945. Dapat dikatakan, Professor Hans Kelsen-lah yang banyak berperan dalam penyusunan UUD Austria 1920 itu, terutama berkenaan dengan ide Mahkamah Konstitusi ini diikuti oleh Italia yang mengadopsikannya dalam UUD pada 1947. Untuk pembentukan Mahkamah Konstitusi itu, di Italia dibentuk undang-undang khusus pada 1948. Perancis baru membentuk lembaga ini, totapi bukan dengan sebutan Mahkamah melainkan dengan sebutan Dewan (counseil constitutionel) pada 1958. Idenya diadopsikan ke dalam UUD yang berlaku sejak 4 Oktober 1958, dan satu bulan kemudian diatur dengan undang-undang tentang Mahkamah Konstitusi yang disahkan pada tanggal 7 November 1958. Selain Austria, Italia, dan Perancis, negara yang paling sering disebut dan bahkan dijadikan model oleh banyak negara dalam soal Mahkamah Konstitusi ini adalah Jerman yang baru mengadopsikan ide Mahkamah Konstitusi ini dalam konstitusinya pada 1949 (sebelum Perancis, tapi sesudah Austria dan Italia)?

Di Jerman, Austria dan Italia, Mahkamah Konstitusi (Constitutional Court) dibentuk tersendiri di samping Mahkamah Agung (Supreme Courf). Namun, tidak semua negara mengikuti jejak ketiga negara ini. Orang Perancis cenderung menganggap kegiatan lembaga baru ini sama sekali tidak dapat. dikategorikan sebagai kegiatan peradilan dalam arti yang lazim. Karena itu, ide lembaga ini diadopsi tetapi namanya bukan 'Constitutional Court, melainkan "Constitutional Counseif atau dalam bahasa Perancis disebut "Counseil Constitutiona". Semua negara bokas jajahan Perancis pada umumnya mengikuti pola Perancis ini. Berbeda dengan orang Perancis dan Jerman, orang Belgia mengembangkan pengertiannya sendiri mengenai fungsi kelembagaan Mahkamah ini. Pengadilan konstitusional yang dimaksud memang bukan peradilan dalam arti yang sebenarnya, tetapi tetap berfungsi sebagai penyelesaian sengketa. Karena itu, dalam konstitusi Belgia; kelembagaannya disebut dengan nama "Constitutional Arbitrage" atau Arbitrase Konstitusional.

Selain ketiga jenis negara-negara tersebut, ada pula beberapa negara yang memiliki Mahkamah Konstitusi, tetapi kedudukannya ada di dalam lingkup tugas dan kewenangan Mahkamah Agung. Contohnya adalah Republik Venezuella. Dalam UUD Venezuella ditentukan adanya 'tribunal constitutiona/atau Mahkamah Konstitusi sebagai salah satu kamar dalam lingkungan Mahkamah Agung. Beberapa negara Amerika Selatan lainnya banyak juga yang menganut pandangan yang sama sekali tidak mempunyai Mahkamah Konstitusi' sama sekall. Fungsi Mahkamah Konstitusi itu, seperti di Amerika Serikat dianggap cukup diberikan atau dikaitkan dengan Mahkamah Agung saja. Di Asia juga banyak negara yang mengikuti pola Amerika Serikat ini, termasuk negara-negara yang baru saja melakukan'constitutional reform' dan berubah secara signifikan mẹnjadi negara demokrasi, seperti misalnya Filipina.

7 /bid. 
Penyebutan Filipina sebagai satu negara yang mengalami 'constitutional reform' dan berubah secara revolusioner dari 'otoritarian' menjadi 'demokrasi', sangatlah penting karena pada umumnya negara-negara yang mengalami gejolak sosial politik dan konstitusional pada dasawarsa 1980-an dan 1990-an sangat akrab dengan ide pembentukan Mahkamah Konstitusi ini. Sesungguhnya, Jerman dan Italia juga baru mengadopsikan gagasan pembentukan Mahkamah Konstitusi ini setelah lepas dari cengkraman diktator Adolf Hitler dan Benito Musolini pasca perang Dunia kedua. Oleh karena itu, dapat dikatakan bahwa pembentukan lembaga peradilan Mahkamah Konstitusi ini di dunia terkait dengan upaya yang baru saja mengalami gejolak.

Dalam hubungan itulah maka pada kurun dasawarsa 1980-an dan 1990-an, banyak sekali negara-negara eks komunis yang mengalami keruntuhan dan kemudian berubah menjadi negara demokrasi. Semua negaranegara komunis itu menganut prinsip 'supreme parlemen' (supremacy of parliament). Hal ini tercermin pada adanya lembaga yang mempunyai kedudukan tertinggi dalam struktur ketatanegaraan mereka. Negaranegara, seperti RRC, Uni Soviet, Bulgaria, Romania, Cekoslavakia, Cuba, dan lain sebagainya menganut prinsip supremasi parlemen ini. Indonesia di bawah UUD 1945 (sebelum mengalami perubahan) juga menganut sistem MPR sebagai lembaga tertinggi negara. Kerajaan Inggeris meskipun seperti Indonesia bukan negara komunis, juga menganut prinsip 'supremacy of parliament."
Di semua negara yang menganut pola pemikirạn terakhir ini, tidak dikenal adanya fungsi pengujian terhadap konstitusionalitas undang-undang oleh hakim. Prinsip pemisahan kekuasaan (separation of power) yang tegas antar cabang-cabang kekuasaan negara yang mengharuskan diberlakukannya sistem 'cecks and balances'di antara fungsi-fungsi kekuasaan itu dianggap tidak diperlukan ataupun justru dianggap bertentangan dengan doktrin supremasi parlemen itu sendiri. Karena itu, undang-undang sebagai produk lembaga legislatif dianggap hanya dapat diuji oleh lembaga yang membuatnya sendiri. Jika misalnya sepert dalam UUD 1945 yang asli, undang-undang ditentukan merupakan produk Presiden bersama DPR, maka hanya Presiden bersama. DPR sajalah yang dianggap berwenang untuk menguji undang-undang itu, baik secara formal (formal review) ataupun secara material (material review).

Dengan demikian, dalam hubungannya dengan bentuk-bentuk pengorganisasian fungsi Mahkamah Konstitusi, kita dapat membedakan negara-negara yang ada di dunia sekarang ini ke dalam 6 -kelompok. Keenam kelompok negara-negara itu dapat dijadikan model pengorganisasian berkenaan dengan fungsi kelembagaan Mahkamah Konstitusi (constitutional court). Pertama adalah model Jerman yang memiliki Mahkamah Agung dan Mahkamah Konstitusi sebagai dua organ yang sederajat dan terpisah. Kedua adalah Perancis yang menyebut lembaga 'itu dengan 'Dewan Konstitusi' (Counseil Constitutionnal) di samping struktur Mahkamah Agung yang tersendiri. Ketiga,

\footnotetext{
${ }^{8} /$ bid.
} 
model Belgia yang menyebut lembaga ini dengan nama 'Constitutional Arbitrage'. Disamping Mahkamah Konstitusi tetapi fungsinya dijalankan langsung oleh Mahkamah Agung. Keenam, model negaranegara yang menganut sistem supremasi parlemen yang sama sekali tidak mengenal lembaga Mahkamah Konstitusi dan juga tidak mengakui adanya fungsi 'judicial review' atas konstitusionalitas undang-undang yang diakui sebagai fungsi pokok terpenting yang menyebabkan Mahkamah Konstitusi harus ada.

Negara Indonesia, dapat dikatakan merupakan negara ke-78 yang tercatat mengadopsikan gagasan pembentukan Mahkamah Konstitusi. Gagasan pembentukan Mahkamah Konstitusi tidak lain merupakan dorongan dalam penyelenggaraan kekuasaan dan ketatanegaraan yang lebih baik. Paling tidak ada empat hal yang melatarbelakangi dan menjadi pijakan dalam pembentukan Mahkamah Konstitusi yaitu: (1) Sebagai implikasi dari paham konstitusionalismo; (2) Mekanisme check and balances; (3) Penyelenggaraan negara yang bersih; dan (4) Perlindungan terhadap hak asasi manusia. ${ }^{9}$

Jika dilihat kedudukannya dalam struktur ketatanegaraan Republik Indonesia yang menempatkan Mahkamah Konstitusi sejajar di samping dan terpisah dengan Mahkamah Agung, maka model pengorganisasiannya mencontoh model Mahkamah Konstitusi Jerman dan Perancis. Kehadiran Mahkamah Konstitusi setelah perubahan UUD 1945 begitu penting untuk' mewujudkan checks and bal- ances terhadap produk UU yang dibuat oleh DPR dan Pemerintah. Paling tidak, Mahkamah Konstitusi bisa mengekang supremasi parlemen (legislative haevy) yang diberikan oleh UUD 1945.

\section{Kedudukän dan Kewenangan Mahkamah Konstitusi}

Berdasarkan Pasal 24 ayat (2) UndangUndang Dasar 1945 kedudukan Mahkamah Konstitusi dalam struktur ketatanegaran Indonesia adalah paralel atau sederajat dengan Mahkamah Agung, yaitu termasuk ke dalam lingkungan kekuasaan kehakiman. Namun, yurisdiksi antara Mahkamah Konstitusi dengan Mahkamah Agung ditentukan secara limitatif sehingga mempunyai kewenangan yang berbeda.

Sesuai dengan hasil perubahan UndangUndang Dasar 1945 Pasal 24C ayat (1) dan Pasal 1 Peraturan Mahkamah Agung (Perma) Nomor 2 Tahun 2002 Mahkamah Konstitusi memiliki lima kewenangan yaitu, Mahkamah Konstitusi berwenang mengadili pada tingkat pertama dan terakhir yang putusannya bersifat final untuk menguji undang-undang terhadap undang-undang dasar, memutus sengketa kewenangan lembaga negara yang kewenangannya diberikan oleh undang-undang dasar, memutus pembubaran partai politik, dan memutus perselisihan tentang hasil pemilihan umum. Dengan kata lain, kompetensi absolut yang dimiliki oleh Mahkamah Konstitusi mencakup tiga kategori yaitu, constitutional review dan sengketa antarlembaga negara,

${ }^{9}$ A. Fickar Hadjar dkk, Pokok-pokok Pikiran dan Rancangan Undang-Undang Mahkamah Konstitusi, Cetakan I. (Jakarta: KRHN dan Kemitraan, 2003), him.3. 
impeachment process, serta perkara politik berupa sengketa dan pembubaran partai, 10

Kewenangan yang dimiliki oleh Mahkamah Konstitusi dalam melakukan uji materi (judicial review) terhadap undang-undang tersebut di atas, telah terjadi kerancuan, bahkan bertabrakan dengan Tap MPR No III/MPR 2000 Tentang Sumber Hukum dan Tata Urutan Perundang-undangan Pasal 5 ayat (1) yang menyatakan:" Majelis Permusyawaratan Rakyat, berwenang menguji undang-undang terhadap undang-undang dasar dan Ketetapan MPR. Sedangkan menurut Pasal $24 \mathrm{C}$ ayat (1) yang berhak menguji undang-undang terhadap undang-undang dasar adalah Mahkamah Konstitusi. Disamping itu, terjadi tidak proporsionalnya antara Mahkamah Agung dan Mahkamah Konstitusi dalam hal konflik peraturan dengan konflik orang. Idealnya, pengujian peraturan perundang-undangan dilakukan oleh satu lembaga, sehingga menutup terjadinya inkonsistensi. putusan dan tegasnyavisi dan konsepsi hukumyang hendak ditegakkan. Seharusnya konflik peraturan ada pada satu atap yaitu Mahkamah Konstitusi, sedangkan konflik orang ada pada Mahkamah Agung.

Masalah lain yang kontroversial adalah pembatasan lembaga negara yang bisa bersengketa kewenangan, yaitu hanya MPR, Presiden, DPR, BPK, dan Bank Sentral (Pasal 1 ayat (12) Perma No. 2 Tahun 2002). Padahal, Lembaga negara yang diberi wewenang UUD adalah MPR, Presiden, BPK, DPR, MA, MK, Komisi Yudisial, KPU, dan Pemerintah Daerah. Di satu sisi, Mahkamah Agung mempersempit keberadaan lembaga negara yang diberi wewenang oleh UUD, tapi di sisi lain juga memperluasnya. Misalnya, Bank Sentral dimasukkan sebagai lembaga negara yang bisa jadi subyek sengketa ,kewenangan, padahal UUD tidak memberi wewenang secara langsung tapi oleh UU (Pasal 23-D UUD 1945). Di sisi lain ada lembaga negara yang diberi wewenang oleh UUD, tapi tidak dimasukkan sebagai obyek penyelesaian sengketa Mahkamah Konstitusi.

Jika begitu, sulit merumuskan bagaimana operasional terhadap wewenang dan kewajiban Mahkamah Konstitusi dalam pembuatan RUU-nya, karena rumusan UUD yang jadi rujukan tidak jelas dan tegas bagaimana filosofis dibentuknya Mahkamah Konstitusi, mestinya Mahkamah Konstitusi berfungsi sebagai "penjaga keseimbangan" antara UUD dan peraturan perundangundanganyang dinaunginya untuk merefleksikan cheks and balances. Mahkamah Konstitusi perlu dicegah dari kemungkinan timbulnya arogansi baru yang seolah-olah Mahkamah Konstitusilah satu-satunya penafsir UUD, Bila tidak, maka Indonesia kembali terjebak pada masa Orde Baru di mana penguasa (Presiden) yang memonopoli kebenaran UUD. ${ }^{11}$

Sesuai dengan Aturan Tambahan Pasal 1 Hasil Perubahan Undang-Undang Dasar 1945, akibatberubahnya sistem ketatanegaraan Indonesia, di masa yang akan datang kita tidak akan mengenal lagi produk-produk MPR. Kemudian yang menjadi pertanyaan adalah, apakah Mahkamah Konstitusi berwenang menguji TAP MPR tersebut? Jika Aturan Peralihan UUD 1945 tidak menegaskan bahwa status TAP MPR/S di masa depan

${ }^{10}$ Fajrul Falaakh, Kritik atas Mahkamah Konstitusi, Htm, him. 3

" Harian Media Indonesia. 13 Januari 2003 
sebagai peraturan setingkat undang-undang, maka Mahkamah Konstitusi tidak berwenang mengujinya, karena Mahkamah Konstitusi hanya berwenang menguji undang-undang. Sesuai dengan rumusan Aturan Tambahan Pasal 1 tersebut, nasib TAP MPR akan ditentukan tahun 2003 ini (TAP MPR ada yang dirubah menjadi undang-undang dan ada yang dicabutt).12

Selain kewenangan yang digariskan dalam Pasal $24 \mathrm{C}$ ayat (1) di atas, kewenangan konstitusional lainnya dari Mahkamah Konstitusi dapat ditemukan pada Pasal $7 \mathrm{~B}$ ayat (1) dan ayat (4)hasil perubahan UndangUndang Dasar 1945, yang menegaskan, Mahkamah Konstitusi wajib memeriksa, mengadili dan memutus dengan seadiladilnya terhadap pendapat Dewan Perwakilan Rakyat bahwa Presiden dan/atau Wakil Presiden telah melakukan pelanggaran hukum berupa pengkhianatan terhadap negara, korupsi, penyuapan, tindak pidana berat lainnya, atau perbuatan tercela, dan/atau pendapat bahwa Presiden dan/atau Wakil Presiden tidak lagi memenuhi syarat sebagai Presiden dan/atau Wakil Preșiden.

Dilibatkannya Mahkamah Konstitusi dalam proses pemberhentian Presidendan/ atau Wakil Presiden tidak terlepas dari pengalaman masa lalu dan merupakan konsekuensi logis dari perubahan sistem yang dikembangkan di Indonesia. Selain itu, keinginan untuk memberikan pembatasan agar seorang Presiden dan/atau Wakil
Presiden diberhentikan bukan karena alasan politik belaka, tetapi juga memiliki landasan dan pertimbangan hukum yang dapat dipertanggungjawabkan.

Meski demikian, konsepsi yang dibangun oleh Konstitusi dalam proses pemberhentian Presiden dan/atau Wakil Presiden masih menyisakan beberapa persoalan diantarnya; Pertama, tidak adanya kriteria yang jelas mengenai konteks "pidana berat lainnya" atau "perbuatan tercela" sehingga memungkinkan terbukanya penafsiran secara semena-mena. Dalam Hal ini Yusril mengemukakan, apakah istilah "perbuatan tercela" itu merupakan tindak pidana atau suatu kaidah moral. Kalau dia merupakan kaidah moral, maka bagaimana suatu majelis hakim konstitusi yang menjalankan kekuasaan kehakiman harus memutus sesuatu yang berada pada tataran kaidah moral dan bukan suatu kaidah hokum. Begitu juga pengertian "melakukan tindak pidana berat lainnya" harus diperjelas dari segi hukum pidana, apakah yang dimaksud dengan "tindak pidana berat lainnya" itu. "Apakah seperti yang dimaksud Kitab Undang-undang Hukum Pidana (KUHP) ataukah bukan, ataukah kita mendefinisikan sendiri. ${ }^{13}$ Kedua, apa dan bagaimana mekanisme pemeriksaaan oieh Mahkamah Konstitusi mengingat dugaan yang dimaksud oleh DPR adalah perbuatanperbuatan yang terkait dengan tindak pidana. Apakah cukup waktu 90 hari untuk memeriksa dan memutus dugaan pelanggaran Presiden/ Wapres jika mengingat proses acara pidana

'2Persoalan ini telah diputuskan dalam Sidang Tahunan MPRRI 2003 melalui Ketetapan MPR RI No. I/ MPR2003 tentang Peninjauan Terhadap Materi dan Status Hukum Ketetapan MPRS dan Ketetapan MPR RI 1960 Sampai Dengan 2002.

${ }^{13}$ Harian Kompas, tanggal 1 Agustus 2003 
yang harus menentukan kebenaran materiil dalam suatu kasus itu bisa memakan waktu berbulan-bulan? Ketiga, bagaimana sifat mengikat putusan Mahkamah Konstitusi untuk memberhentikan Presiden dan/atau Wakil Presiden, mengingat putusan dari Mahkakah Konstitusi. harus dibawa oleh DPR ke MPR. Tidak tertutup kemungkinan MPR menganulir putusan Mahkamah Konstitusi. ${ }^{14}$

Merujuk pada hasil perubahan ketiga Undang-Undang Dasar 1945 sebagaimana ditentukan pada Pasal 24C ayat (1) dan Pasal $7 \mathrm{~B}$ ayat (1) dan ayat (4) maka kewenangan Mahkamah Konstitusi dalam sistem ketatanegaraan Indonesia dapat di elaborasi dalam enam hal, yaitu : $:^{15}$

1. Melakukan pengujian undang-undang terhadap undang-undang dasar;

2. Memutuskan sengketa kewenangan antar lembaga negara;

3. Memutus pembubaran partai politik;

4. memutus perselisihan tentang hasil pemilihan umum;

5. Memeriksa, mengadili dan memutus pendapat DPR bahwa Presiden dan/atau Wakil Presiden telah melakukan pelanggarana hukum berupa pengkhianatan terhadap negara, korupsi, penyuapan, tindak pidana berat lainnya, atau perbuatan tercela;

6. Memeriksa, mengadili dan memutus pendapat DPR bahwa Presiden dan/atau Wakil Presiden telah tidak lagi memenuhi syarat sebagai Presiden dan/atau Wakil
Presiden.

Mengenai keanggotaan Mahkamah Konstitusi, menurut Pasal $24 \mathrm{C}$ ayat (3) bahwa "Mahkamah Konstitusi mempunyai sembilan orang anggota Hakim Konstitusi yang ditetapkan oleh Presiden, yang diajukan masing-masing tiga orang oleh Mahkamah Agung, tiga orang oleh Dewan Perwakilan Rakyat, dan tiga orang oleh Presiden".

Melihat komposisi Hakim Mahkamah Konstitusi tersebut, nampak bahwa pengisian keanggotaan Mahkamah Konstitusi yang dimonopoli oleh Presiden, DPR, dan MA tidak membuka peluang adanya peran rakyat. Keistimewaan ketiga lembaga ini juga bersifat diskriminatif terhadap DPD, BPK, dan KPU. Model Mahkamah Konstitusi ini terkesan mengimpor mentah-mentah dari Perancis dan Jerman (Barat). Namun, Presiden di Perancis dan di Jerman bukan Kepala Pemerintahan seperti di Indonesia. Maka, Presiden Indonesia akan menentukan arah Mahkamah Konstitusi melalui dua jalur, jalur kepresidenan dan jalur partai-partai di DPR. Kondisi :ini rawan, karena rekayasa sistem hukum bernegara selain dalam konstitusi, juga berpotensi terjadj pada tingkat undang-undang. Yaitu, bila terjadi kolusi antara Presiden dengan DPR. Keduanya dapat membuat sistem hukum yang akan mengontrol hampir semua lini kehidupan bernegara. Melalui fungsi legislasi yang dimilikinya, DPR dan P.residen dapat membuat undang-undang yang mengatur segala sesuatu tentang diri sendiri, DPD. MA.

\section{${ }^{14}$ A. Fickar Hadjar dkk. op. cit. hlm.17}

${ }^{15}$ Dahlan Thaib, Mahkamah Konstitusi dalam Sistem Ketatanegraan Indonesia, makalah yang cisampaikan pada Seminar Regional "Keoudukan, Fungsi dan Kompetensi Mahkamah Konstitusi Dalam Sistem Ketatanegaraan Republik Indonesia", diselenggarakan oleh Program Doktor (S3) IImu Hukum, Universitas Islam Indonesia, Yogyakarta, 11 Mei 2002, him.3 
BPK, Komlsi Yudisial, Pemilu, Partal Polltik, Pertahanan dan Keamanan negara, penegakan HAM dan lain-lain. Dalam hal inl yang perlu di garis bawahl adalah kolusi antara DPR dengan Presiden Juga berpotensi memandulkan peran strategis Mahkamah Konstitusi.

Hakim Konstitusl yang ditetapkan berJumlah sembilan orang yang diajukan masingmasing tiga orang oleh DPR, Presiden dan $M A_{1}$ hal Inl dimaksudkan agar Mahkamah. Konstitusi dapat bertindak adil. Yang menjadl persoalan adalah bagaimana cara seleksi atau rekrutmennya? Jika hal itu dlserahkan juga kepada masing-masing lembaga yang mengajukan, dikhawatirkan tidak akan terdapat parameter yang sama dan akan menghasilkan kredibilitas hakim konstitusi yang berbeda. Disamping Itu, tidak menutup kemungkinan hakim konstitusi dari DPR akan sama dengan hakim konstitusi dari Presiden dan MA. Persoalannya akan berbeda jika pelaksanaan ujl kepatutan dan kelayakan (fit and proper test) dilakukan 'oleh satu badan atau lembaga khusus, dengan terlebih dahulu, proses penjaringan dan seleksi bakal calon hakim konstitusi dilakukan oleh masingmasing lembaga melalul tahapan-tahapan yang ditentukan ketiga lembaga tersebut dengan mellbatkan partisipasi masyarakat, baru kemúdian dari beberapa bakal calon tetap tersebut, misalnya ditentukan maksimal 6 orang darl masing-masing lembaga untuk diajukan ke lembaga khusus tersebut guna. menentukan siapa yang berhak diangkat menjadi hakim konstitusi. Melalui cara seperti ini duplikași bakal calon hakim konstitusi dapat dihindari.

\section{Sistem Pemerintahan Presidens|ll}

Ada tiga sistem pemerintahan yaitu a). Sistem pemerintahan parlementer; b). Sistem pemerintahan presidensill; dan c). Sistem pemerintahan referendum. Namun, di sini penulis hanya ingin sedikit menguraikan tentang sistem yang berhubungan dengan pokok bahasan dalam makalati ini yaltu, sistem presidensill.

Dalam sistem presidensill, masa jabatan Kepala Pemerintahan secara konstitusional selalu ditentukan dengan tegas. Misalnya, dl Amerlka Serlkat dibatasi hanya 2 kall masa Jabatan.: Kebiasaan dalam sistem ini tidak terdapat dalam sistem lain. DI Indonesia, melalui perubahan UUD 1945 masa jabatan Presiden pun ditentukan secara tegas, yaitu hanya 2 kall masa jabatan, sesual ketentuan Pasal 7 yang berbunyi:" Presiden dan Wakil Presiden memegang jabatan selama lima tahun, dan sesudahnya dapat dipilih kembali dalam jabatan yang sama, hanya untuk satu kali masa jabatan".

Adanya masa jabatan yang pasti ini memberikan keuntungan tersendiri bagi sistem presidensill. Pertama, stabilitas pemerintahan dapat dipelihara. Presiden terlindungi dari pengaruh yang diakibatkan oleh perubahan polititk di parlemen, misalnya karena perubahan komposisi.mayoritas yang berhasil dikuasal oleh partal oposisi, ataupun karena Presiden dan kabinet yang dipimpinnya kehilangan kepercayaan dari rakyat dan para wakil rakyat di parlemen; kedua, sebagai akibat adanya stabilitas pemerintahan itu, maka porencanaan dan pelaksanaan pembangunan dapat berjalan secara konsisten tanpa terganggu oleh perubahan politik; ketiga, pelaksanaan tugas pemerintahan dan 
pembangunan tidak tergantung kepada suara para anggota parlemen yang kadang-kadang bersifat parokial dan berorientasi pada kepentingan lokal dan sempit.

Kelebihan sistem presidensiil adalah :Pertama, stabilitas eksekutif, hal ini didasarkan pada masa jabatan Presiden. Kedua, pemilihan Kepala Pemerintahan oleh rakyat dapat dipandang lebih demokratis dari pemilihan tak langsung. Ketiga, pemisahan kekuasaan berarti pemerintahan yang dibatasi, perlindungan kebebasan individu atas tirani pemerintah.

Kelebihan sistem presidensiil sekaligus merupakan kekurangan dari sistem tersebut, yaitu: Pertama, masalah kemandegan atau konflik eksekutif-legislatif, yang bisa berubah menjadi "jalan buntu" dan "kelumpuhan" adalah akibat dari ko-eksistensi dari dua badan independen yang diciptakan oleh pmerintahan presidentil dan yang mungkin bertentangan. Bila pertentangan kedua badan itu terjadi. Maka tidak ada sumber daya institusional untuk memecahkannya, tidak seperti faktor mosi legisiatif yang menjaga legislator dan eksekutif tetap sejalan dalam sistem parlementer. Kedua, adalah kekakuan temporal. Linz memulis bahwa masa jabatan Presiden yang pasti menguarikan periode-periode yang dibatasi secara kaku dan tidak berkelanjutan, sehingga tidak memberikan kesempatan untuk melakukan berbagai penyesuaian yang dikehendaki oleh keadaan. Bagehot pun menyatakan bahwa presidensialisme tidak memiliki unsur elastis:"segala sesuatu ditetapkan secara kaku", dan "sikap revolusioner" yang dibutuhkan oleh pemerintah sama sekali tidak ada. Masalah ini diperburuk oleh ketentuan bagi Wakil Presiden yang menggantikan Presiden secara otomatis jika Presiden meninggal dunia atau tidak mampu lagi menjalankan tugasnya, pengganti otomatis ini dipilih sebelumnya sehingga bukan merupakan orang yang paling tepat dalam keadaan baru di masa suksesi itu berlangsung, semua alasan politik selain syarat-syarat Presiden cenderung mempengaruhi pemilihan Wakil Presiden. Ketiga, sistem ini berjalan atas dasar aturan "pemegang menguasai semuanya" yang cenderung membuat politik demokrasi sebagai sebuah permainan dengan semua potensi 'kọnfiknya. ${ }^{16}$

Dalam pemilihan Presiden, hanya seorang calon dan satu partai yang bakal menang, dan orang lain kalah. Selain itu, konsentrasi kekuasaan di tangan Presiden memberinya sangat sedikit insentif untuk membentuk koalisi atau sistem pembagian kekuasaan lainnya atau untuk mengambil bagian dalam negosiasi dengan pihak oposisi yang mungkin diperlukan untuk menghadapi berbagai masalah yang memecah belah. Terutama di negara yang telah terbagi dan terpolarisasi, aturan "pemenang menguasai semuanya" sangat mungkin menimbulkan pembagian dan polarisasi lebih lanjut. Politik menjadi eksklusif, bukan inklusif.

${ }^{16}$ Ibrahim R. (Penyadur dkk.), Sistem Pemerintahan Parlementer dan Presidensial (Jakarta: Rajagrafindo Press, 1995). 


\section{Urgensi Mahkamah Konstitusi dalam Proses Pemberhentian Presiden}

Hasil Perubahan Ketiga Undang-Undang Dasar 1945 memang berbeda apabila dibandingkan dengan perubahan pertama dan perubahan kedua. Perbedaan itu disebabkan, dalam perubahan terdapat nuansa politik sangat kental, di antaranya menyangkut pelaksanaan kedaulatan rakyat dan perubahan sistem pemerintahan yang dianut. $\mathrm{Hal}$ ini berkenaan dengan eksistensi Majelis Permusyawaratan Rakyat.

Dalam perubahan ketiga terdapat materi muatan sistem pemerintahan yang lebih mempertegas $k \theta$ arah sistem pemerintahan presidensiil. Sebelumnya Undang-Uridang Dasar 1945 menganut sistem pemerintahan campuran, di satu pihak mengandung segi presidensill (Pasal 4 jo. Pasal 17), sedang di lain pihak mengandung segi parlementer. Segi pemerintahan parlementer ini terletak pada hal-hal berikut:

1. Presiden dan Wakil Presiden dipilih oleh MPR (Pasal 6)

2. Presiden bertindak dan bertanggungjawab kepada MPR (Penjelasan Umum Tentang Sistem Pemerintahan Negara, Nomor III, angka (3)

Ciri kedua tersebut kemudian djjabarkan dalam Ketetapan Majelis Pernusyawaratan Rakyat No. I/MPR/1983 Tentang Peraturan Tata Tertib Majelis Permusyawaratan Rakyat Republik Indonesia yang antara lain me- nyatakan:

Majelis Permusyawaratan Rakyat berwenang:

a. meminta pertanggungjawaban dari Presiden dan menilai pertanggungjawaban tersebut;

b. memberhentikan Presiden dalam masa jabatannya apabila Presiden melanggar Garis-garis Besar Haluan Negara dan/atau Undang-Undang Dasar 1945.

Pertanggungjawaban ini lebih dekat dengan sistem "impeachment" di Amerika Serikat. Dengan demikian, sistem Indonesia secara hakiki adalah sistem presidensiil, bukan dimaksudkan sebagai bentuk campuran. ${ }^{17}$ Berbeda dengan Șri Soemantri, berdasarkan ketentuan UUD 1945, yaitu di satu pihak Presiden sebagai penyelenggara pemerintahan (presidensill) dan di pihak lain Presiden bertanggung jawab kepada MPR (badan perwakilan), Sri Soẹmantri menyatakan bahwa sistem pemerintahan RI berdasarkan UUD 1945 memperlihatkan selakigus segi-segi sistem pemerintahan presidensiil dan sistem pemerintahan parlementer atau sistem campuran..$^{18}$

Melalui perubahan ketiga, telah dianut siștem pemerintahan presidensill (murni). Hal. ini. terlihat dari ciri-ciri sistem pemerintahan presidensiil sebagaimana dikemukakan oleh S.L. Witman dan J.J Wuest dalam bukunya Visual Outline of Comparative Government, yang dikutip kembali oleh Sri Soemantri, ${ }^{19}$

${ }^{17}$ Bagir Manan, Lembaga Kepresidenan (Yogyakarta: Gama Media bekerja sama dengan PSH. FH. UII, 1999), hlm 41

${ }^{18}$ Sri Soemantri M, Ketetapan MPR(s) Sebagai Salah Satu Sumber Hukum Tata Negara (Bandung: Remaja, 1988), hlm. 15.

${ }^{19}$ Sri Soemantri, Catatan-catatan Tertadap RUU RI Nomor..., Tahun2002 Tentangmahkamah Konstitusi, makalah disampaikan pada Seminar Regional, "Kedudukan, Fungsi da Kompetensi Mahkamah Konstitusi Dalam 
bahwa ciri-ciri sistem pemerintahan presidensill (Presidential Government atau Fixed Executive System) adalah sebagi berikut:

1. It is based upon the separation of power principle;

2. The executive has no power to dissolve the legislative nor must he resign when he loses the support of the majority of its membership;

3. There is no mutual responsibitity between the President and his Cabinet; the latter is wholly responsible to the Chief Executive;

4. The executive is chosen by the electorate. Ciri kedua, ketiga dan keempat terdapat dalam UUD 1945, melalui perubahan pertama dan perubahan ketiga. Dalam perubahan ketiga ditegaskan, calon Presiden dan calon Wakil Presiden dalam satu pasangan dipilih oleh rakyat dalam pemilihan umum. Ini berarti Presiden tidak akan bertanggung jawab kepada lembaga negara apa pun. Karena sebagai manusia, Presidendan/atau Wakil Presiden dapat melanggar hukum, muncullah Mahkamah Konstitusi yang salah satu tugas dan wewenangnya adalah memeriksa, mengadili, dan memutuskan pendapat DPR bahwaPresiden dan /atau WakilPresiden telah melakukan pelanggaran hukum berupa pengkhianatan terhadap negara, korupsi, penyuapan, tindak pidana berat lainnya, atau perbuatan tercela maupun apabila terbukti tidak lagi memebuhi syarat sebagai Presiden dan/atau Wakil Presiden.

Demikian juga dengan di Amerika Serikat,
Presiden AS tidak tunduk dan bertanggung jawab kepada badan perwakilan (Congress). Apapun perbedaan pandangan antara Presiden dan Congress, Presiden akan tetap sampai habis masa jabatannya (fixed executive). Satu-satunya jalan untuk menjatuhkan presiden Amerika Serikat (dalam masa jabatannya) adalah melalui "impeachmenf" atau disebut juga "trial by Congress". Tetapi dasar untuk impeachmnet sangat terbatas, baik secara substansial maupun prosedural tidak mudah dilaksanakan. Impeachment hanya dapat dilaksanakan apabila Presiden melakukan "treson, bribery, or other high crimes and misdemeanors". ${ }^{20}$

DiAmerika Serikat, tata cara pemberhentian Presiden diatur dalam UUD. Tetapi hal tersebut tidak menghalangi tumbuh praktik yang memahamkan bahwa prinsip stabilitas pemerintahan harus tetap dipertahankan walaupun ada "impeachmenf". Karena itu, hingga kini baru dua orang Presiden Amerika Serikat terkena impeachment, itu pun tidak berhasil. ${ }^{21}$

Di Indonesia, setelah adanya perubahan UUD 1945 tata cara pemberhentian Presiden dan/atau Wakil Presiden juga diatur melalui UUD (1945) sebagaimana tercantum di dalam Pasal 7A, Pranata impeachmentpun disediakan untuk Presiden dan/atau Wakil Presiden jika melakukän pelanggaran terhadap Pasal 7A tersebut. Namun, proses dan prosedur untuk molaksanakan impeachment sangat sulit, seperti yang kita lihat ketentuan dalam Pasal 7B UUD 1945 Hasil Perubahan.

Sistem Ketatanegaraan Republik Indonesia", diselenggarakan oleh Program Doktor (S3) Ilmu Hukum, Universitas Islam Indonesia, Yogyakarta, 11 Mei 2002, hlm. 3.

${ }^{20}$ BagirManan, Ibid., hm. 38-39.

${ }^{21}$ Bagir Manan, Ibid., hIm. 43 
Salah satu alasan munculnya gagasan pembentukan Mahkamah Konstitusi adalah ketika terjadi konflik antara Dewan Perwakilan Rakyat dengan Presiden, tidak ada lembaga yang secara konstitusional berwenang untuk menyelesaikan persoalan atau pertengkaran di antara keduanya,

Melalui Perubahan Ketiga UndangUndang Dasar 1945 khususnya Pasal $24 \mathrm{C}$ ayat (2) diatur bahwa: "Mahkamah Konstitusi wajib memberikan putusan atas pendapat Dewan Perwakilan Rakyat mengenai dugaan pelanggaran oleh Presiden dan/atau Wakil Presiden menurut Undang-Undang Dasar". Pasal tersebut memberikan kewenangan kepada Mahkamah Konstitusi untuk terlibat dalam proses pemberhentian Presiden dan/atau Wakil Presiden.

Berdasarkan Pasal 7B dan Pasal $24 \mathrm{C}$ ayat (2), proses pemberhentian Presiden dan /atau Wakil Presiden di Indonesia menganut sistem bertingkat atau sistem gabungan artinya, kasus pelanggaran yang diduga dilakukan oleh Presiden dan /atau Wakil Presiden dibawa ke Mahkamah Konstitusi baru dilakukan impeachment. Jadi, prosesnya pertama-tama melalui Pengadilan Politik (proses impechment) kemudian dibawa ke Pengadilan Hukum (Forum Privilegiatum) yaitu Lembaga Mahkamah Konstitusi, baru dibawa ke MPR (kembali ke proses impeachment).

Cara untuk memberhentikan Presiden dan/atau Wakil Presiden secara konstitusional sebagaimana tersebut di atas dapat dijabarkan sebagai berikut:

1. Menurut Pasal $7 B$ ayat (1) Presiden dan/ atau Wakil Presiden bisa diberhentikan karena melanggar hukum dengan mengkhianati negara, korupsi, penyuapan, tindak pidana berat lainnya atau melakukan perbuatan tercela, atau tidak memenuhi syarat lagi sebagai Presiden dan/atau Wakil Presiden.

2. Menurut Pasal $7 B$ ayat (3) jika ingin menjatuhkan Presiden dengan alasan bersalah maka DPR harus bersidang yang dihadiri oleh $2 / 3$ dari semua anggotanya dan $2 / 3$ dari yang hadir menyetujuinya (proses impeachment).

3. Selanjutnya kesimpulan DPR itu disampaikan kepada Mahkamah Konstitusi untuk dinilai secara hukum (forum Privilegiatum). Mahkamah Konstitusi wajib memeriksa, mengadili,dan memutus dengan seadil-adilnya terhadap pendapat DPR tersebut paling lama 90 hari setelah permintaan DPR itu, diterima oleh Mahkamah Konstitusi.

4. Jika Mahkamah Konstitusi memutuskan bahwa:Presiden dan/atau Wakil Presiden benar-benar telah melakukan perbuatan tercela, apalagi melanggar hukum, seperti dituduhkan DPR maka DPR segera bersidang untuk menyampaikan kepada MPR (kembali ke proses impeachment)

5. MPR dapat memberhentikan Presiden dan/atau Wakil Presiden jika pada sidang untuk itu dihadiri oleh sekurang-kurangnya $3 / 4$ dari seluruh anggotanya dan lebih $2 / 3$ yang hadir menyetujui usul pemberhentian itu.

Proses pemberhentian Presiden sebagaimana tersebut di atas nampak aneh, sebab putusan Mahkamah Konstitusi ditunda efektivitas hukumnya, karena DPR harus meneruskan proses pemberhentian Presiden dan/ataú Wakil Presiden kepada MPR. Penundaan efektifitas hukum putusan Mahkamah Konstitusi makin terasa, karena MPR harus menyelenggarakan Sidang 
istimewa dengan memberi kesempatan kepada Presiden dan/atau Wakil Presiden untuk membela diri. Apakah SI-MPR dan pembelaan diri Presiden atau Wakil Presiden serupa dengan proses pembuktian, atau sekedar politik simbolis? Masih belum cukup, efektivitas putusan Mahkamah Konstitusi digantungkan lagi kepada keputusan yang disepakati oleh 50 persen anggota MPR (yaitu oleh $2 / 3$ anggota dari Korum $3 / 4$ ). Bagaimana jika Mahkamah Konstitusi memutuskan bahwa dugaan DPR tidak berdasar, tetapi DPR meneruskan prosesnya ke SI-MPR agar Presiden dan/atau Wakil Presiden diberhentikan? Dapatkah Presiden dan/atau Wakil Presiden yang diberhentikan itu mengadu ke Mahkamah Konstitusi dengan memperkarakan putusan MPR sebagai sengketa kewenangan antarlembaga negara?

Di samping itu, Berdasar kepada mekanisme atau proses pemberhentian Presiden dan/atau Wakil Presiden tersebut di atas, muncul adanya kemungkinan yang berkaitan dengan sudut pandang hukum dan sudut pandang politik. Seperti yang tercantum dalam Pasal 7B ayat (5) UUD 1945 yaitu,"apabila Mahkamah Konstitusi memutuskan bahwa Presiden dan/atau Wakil Presiden terbukti melakukan pelanggaran hukum...; dan/atau terbukti bahwa Presiden dan/atau Wakil Presiden tidak lagi memenuhi syarat..., DPR menyelenggarakan sidang paripurna untuk meneruskan usul pemberhentian Presiden dan/atau Wakil Presiden kepada MPR". Jika dimisalkan proses hukum di Mahkamah
Konstitusi telah selesai, maka dimulailah kembali proses politik di MPR. Berkaitan dengan sudut pandang poilitik, putusan Mahkamah Konstitusi pada hakekatnya tidak akan berpengaruh pada kemungkinan Presiden dan/atau Wakil Presiden akan kalah dalam pertarungan (politik), baik di DPR maupun di MPR. Putusan Mahkamah Konstitusi terlihat hanya sekedar "beban moral (politik)" bagi DPR dan MPR. Karena kedua lembaga tersebut merupakan arena politik, maka segala sesuatunya tergantung kepada dukungan politik atau legitimasinya. ${ }^{22}$

Pemikiran di atas dapat dibuktikan dengan dua (2) contoh sebagai berikut: pertama, tuntutan impeachment terhadap Presiden Amerika Serikat, Bill Clinton. Dalam Sidang ("Pengadilan") Senat yang dipimpin oleh Ketua Mahkamah Agung AS akhirnya memutuskan bahwa, Presiden Bill Clinton tidak perlu.turun dari jabatannya. Hal itu tidak berarti bahwa Presiden Bill Clinton tidak melakukan pelanggaran hukum, tetapi pelanggaran hukum yang dilakukan oleh Presiden Bill Clinton tidak cukup kuat untuk menurunkannya dari jabatan Presiden: Bukti adanya perbedaan antara kesalahian dan hukuman dapat diperhatikan dari pernyataan para senator yang mendukung Presiden untuk tetap duduk dalam jabatannya. Mereka berpendapat bahwa, Presiden memang diakui (terbukti) bersalah, melakukan perbuatan yang tercela, tetapi Presiden tidak perlu diturunkan dari jabatannya. ${ }^{23}$

Sebagai contoh kedua adalah, masalah pelaksanaan SI-MPR Tahun 2001 dalam

${ }^{22}$ Didit Hariadi dan Suhartono (Editor), Mahkamah Konstitusi Lembaga Negara Baru Pengawal Konstitusi (Jakarta: Agarindo Abadi, 2002), hlm. 58.

${ }^{23}$ Ibid. 
rangka meminta pertanggungjawaban Presiden K.H. Abdurrahman Wahid. Dalam kasus tersebut Presiden diminta pertanggungjawabannya dalam kaitannya dengan pelanggaran terhadap Haluan Negara dan. UUD 1945. Tuduhan polanggaran yang dilakukan Presiden K.H. Abdurrahman Wahid itu didasarkan pada dugaan DPR bahwa; Presiden turut serta dalam pencairan dana non-budgeter badan Urusan Logistik (Bulog) atau dana Yayasan Bina Sejahtera (Yanatera) Bulog. Sehari sebelum pengambilan keputusan dalam Sidang Paripurna DPR, tanggal 28 Mei 2001. Jaksa Agung Marzuki Darusman telah mengeluarkan Surat Pemberitahiuan Penghentian Penyidikan (SP3) dengan Alasan, tidak ditemukannya bukti yang cukup mengenai keterlibatan Presiden K.H. Abdurrahman Wahid dalam kasus' Boluggate dan Bruneigate. ${ }^{24}$

Berdasarkan uraian di atas, dapat penulis simpulkan bahwa putusan Mahkamah Konstitusi dalam proses pemberhentian Presiden dan/atau Wakil Presiden nyaris tidak mempunyai "gigi" karena peran lembaga MPR yang sarat dengan muatan politik sangat menentukan, 'apakah Presiden dan/ atau Wakil Presiden masuk dalam "kubangan hukuman" atau sebaliknya.

Dengan demikian, melihat proses dan mekanisme pemberhentian Prsiden dan/ atau Wakil Presiden, dapat dikatakan bahwa proses pemberhentian Presiden dan/atau Wakil Presiden jauh lebih sulit dibandingkan. dengan perubahan undang-undang dasar itu sendiri.

\section{Simpulan}

Berdasarkan uraian di atas, dapat disimpulkan bahwa Mahkamah Konstitusi berfungsi sebagai Pengadilan Hukum dalam proses pemberhentian Presiden dan/atau Wakil Presiden, wajib memberikan putusan atas pendapat Dewan Perwakilan Rakyat mengenai dugaan pelanggaran oleh Presiden dan/atau Wakil Presiden menurut undangundang dasar. Namun, putusan mahkamah Konstitusi terlihat hanya sekedar "beban moral (politik)" bagi 'DPR dan MPR. Karena kedua lembaga tersebut merupakan arena politik, maka sesuatunya tergantung kepada dukungan politik atau legitimasinya.

Kendati hadirnya Mahkamah Kosntitusi telah menimbulkan beberapa problematika dalam pola hubungan kelembagaan negara, namun, keberadaan Mahkamah Konstitusi itu menjadi "cahaya baru" dalam ruang politik. Karena keberadaan Mahkamah Konstitusi merupakan proses hukum yang menentukan kelanjutan dari keinginan DPR untuk mengundang SI-MPR.O

\section{Daftar Pustaka}

Asshiddiqie, Jimly, "Mahkamah Konstitusi di Berbagai Negara", Seminar Regional Kedudukan, Fungsi dan Kompetensi Máhikamah Konstitusi Dalam Sistem Ketatanegaraan Republik Indonesia, diselenggarakan oleh Program Doktor (S3) IImu Hukum, Universitas Islam Indonesia, Yogyakarta, 11 Mei 2002. 
Konsolidasi Naskah UUD 1945 Setelah Perubahan Keempat, Jakarta: Pusat Studi Hukum Tata Negara FHUII, 2002. dan Mustafa Fakhri. Mahkamah Konstitusi Kompilasi ketentuan Konstitusi, Undang-Undang dan Peraturan di 78 Negara. Pusat Studi HTN FH UI. Asosiasi Pengajar HTN dan HAN Indonesia.

Estiko, Didit Hariadi, dan Suhartono (editor), Mahkamah Konstitusi Lembaga Negara Baru Pengawal Konstitusi, Jakarta: Agarindo Abadi, 2003.

Falaakh, Fajrul, Kritik atas Mahkamah Konstitusi. $\mathrm{Htm}$.

Hadjar, A. Fickar dkk, Pokok-Pokok Pikiran dan Rancangan Undang-Undang Mahkamah Konstitusi. Cetakan 1. Konsorsium Reformasi Hukum Näsional dan Kemitraan, Jakarta, 2003.

- Manan, Bagir, Lembaga Kepresidenan, Yogyakarta: Gama Media bekerja sama dengan PSH. FH. Ull, 1999.

DPR, DPD dan MPR dalam UUD 1945 Bain, Cet.1, Yogyakarta: FH-UII Press, 2003.
M, Sri Soemantri, Ketetapan MPR(S) Sebagai Salah Satu Sumber Hukum Tata Negara, Bandung: Remaja, 1988.

"Catatan-catatan Terhadap RUU RI Nomor..., Tahun 2002 Tentang Mahkamah Konstitusi", makalah disampaikan pada Seminar Regional, Kedudukan, Fungsi dan Kompetensi Mahkamah Konstitusi Dalam Sistem Ketatanegaraan Republik Indonesia, diselenggarakan oleh Program Doktor (S3) IImu Hukum, Universitas Islam Indonesia, Yogyakarta, 11 Mei 2002.

Thaib, Dahlan, "Mahkamah Konstitusi dalam Sistem Ketatanegraan Indonesia," makalah yang disampaikan pada Seminar Regional Kedudukan, Fungsi dan Kompetensi Mahkamah Konstitusi Dalam Sistem Ketatanegaraan Republik Indonesia, diselenggarakan oleh Program Doktor (S3) Ilmu. Hukum, Universitas islam Indonesia, Yogyakarta, 11 Mei 2002.

Undang-Undang Dasar 1945 (Amandemen $k e-4)$

UU No. 24 Tahun 2003

Harian Kompas, tanggal 1 Agustus 2003

EOEDEO 